\title{
Effect of propionate on mRNA expression of key genes for gluconeogenesis in liver of dairy cattle
}

\author{
Qian Zhang, Stephanie L. Koser, Brian J. Bequette, and Shawn S. Donkin ${ }^{1}$ \\ Department of Animal Sciences, Purdue University, West Lafayette, IN 47907
}

\begin{abstract}
Elevated needs for glucose in lactating dairy cows are met through a combination of increased capacity for gluconeogenesis and increased supply of gluconeogenic precursors, primarily propionate. This study evaluated the effects of propionate on mRNA expression of cytosolic phosphoenolpyruvate carboxykinase (PCK1), mitochondrial phosphoenolpyruvate carboxykinase (PCK2), pyruvate carboxylase $(P C)$, and glucose-6-phosphatase $(G 6 P C)$, key gluconeogenic enzymes, and capacity for glucose synthesis in liver of dairy cattle. In experiment 1 , six multiparous mid-lactation Holstein cows were used in a replicated $3 \times 3$ Latin square design consisting of a 6 -d acclimation or washout phase followed by $8 \mathrm{~h}$ of postruminal infusion of either propionate (1.68 $\mathrm{mol})$, glucose $(0.84 \mathrm{~mol})$, or an equal volume $(10 \mathrm{~mL} /$ min) of water. In experiment 2, twelve male Holstein calves $[39 \pm 4 \mathrm{~kg}$ initial body weight (BW)] were blocked by birth date and assigned to receive, at $7 \mathrm{~d}$ of age, either propionate $\left[2 \mathrm{mmol} \cdot \mathrm{h}^{-1} \cdot\left(\mathrm{BW}^{0.75}\right)^{-1}\right]$, acetate $\left[3.5 \mathrm{mmol} \cdot \mathrm{h}^{-1} \cdot\left(\mathrm{BW}^{.75}\right)^{-1}\right]$, or an equal volume $(4 \mathrm{~mL} /$ min) of saline. In both experiments, blood samples were collected at $0,2,4,6$, and $8 \mathrm{~h}$ relative to the start of infusion and liver biopsy samples were collected at the end of the infusion for mRNA analysis. Liver explants from experiment 1 were used to measure tricarboxylic acid cycle flux and gluconeogenesis using ${ }^{13} \mathrm{C}$ mass isotopomer distribution analysis from ${ }^{13} \mathrm{C} 3$ propionate. Dry matter intake and milk yield were not altered by infusions in cows. Serum insulin concentration in cows receiving propionate was elevated than cows receiving water, but was not different from cows receiving glucose. Hepatic expression of PCK1 and G6PC mRNA and glucose production in cows receiving propionate were not different from cows receiving water, but tended to be higher compared with cows receiving glucose. Hepatic expression of $P C K 2$ and $P C$ mRNA was not altered by propionate infusion in cows. Blood glucose, insulin, and
\end{abstract}

Received March 18, 2015.

Accepted July 28, 2015.

${ }^{1}$ Corresponding author: sdonkin@purdue.edu glucagon in calves receiving propionate were not different than controls. Calves receiving propionate had increased PCK1 mRNA, tended to have increased G6PC mRNA, and had similar $P C$ mRNA compared with saline controls. These data indicate a tendency for in vivo effects of propionate to alter hepatic gene expression in mid-lactation cows and neonatal calves, which are consistent with a feed-forward effect of propionate to regulate its own metabolism toward gluconeogenesis through changes in hepatic PCK1 mRNA.

Key words: stable isotope, gluconeogenic flux, midlactation dairy cow, calf

\section{INTRODUCTION}

Propionate is the primary precursor for glucose synthesis in dairy cows and contributes as much as 60 to $74 \%$ of the carbon for gluconeogenesis (Aschenbach et al., 2010). Hepatic glucose production is proportional to propionate supply in dairy cows (Baird et al., 1980), and glucose demand to support milk synthesis in the mammary gland increases dramatically at parturition. The transition dairy cow is often challenged in meeting glucose needs due to inadequate feed intake (Bell, 1995). Methods to increase propionate supply as the supply of glucogenic precursors during this critical period include modifications to alter the diet or ruminal fermentation pattern (Duffield et al., 2002, 2003; Overton and Waldron, 2004).

The rate of gluconeogenesis in liver is controlled by activity of several flux-controlling enzymes, including phosphoenolpyruvate carboxykinase $(P C K)$, glucose6-phosphatase $(G 6 P C)$, and pyruvate carboxylase $(P C)$, that are responsive to hormonal and allosteric regulation (Pilkis et al., 1988; Pilkis and Granner, 1992; Aschenbach et al., 2010). Two isoforms of PCK, cytosolic form (PCK1) and mitochondrial form (PCK2), are present. Expression of $P C K 1$ and $G 6 P C$ mRNA were induced by propionate in rat hepatocytes and H4IIE hepatoma cells (Massillon et al., 2003). Although the role of propionate as a regulatory molecule may be questioned in nonruminants due to the low quantities reaching liver, growing evidence in ruminants suggests 
that the expression of $P C K 1$ and capacity for gluconeogenesis from propionate may be linked to feed intake and propionate supply. Studies from our laboratory indicate that expression of $P C K 1$ is elevated when feed intake is increased during early lactation (Greenfield et al., 2000; Agca et al., 2002) and with prepartum supplementation of monensin (Karcher et al., 2007), conditions linked to increased propionate production from the rumen. However, the direct role of propionate on expression of key genes for hepatic gluconeogenesis, including PCK1, has not been determined in dairy cows.

In neonatal calves, hepatic gluconeogenesis is established to prevent hypoglycemia because lactose intake from milk cannot meet glucose requirements (Hammon et al., 2013).

The onset of rumen development is marked by the production and absorption of VFA and hence, an increase in propionate concentration in hepatic portal blood. The rate of gluconeogenesis from propionate is acutely responsive to changes in propionate concentration in hepatocytes from neonatal calves (Donkin and Armentano, 1994). In addition, rates of gluconeogenesis from propionate are similar between preruminant and ruminating calves despite a decrease in gluconeogenesis from lactate (Donkin and Armentano, 1995). However, the effects of prolonged exposure to propionate on hepatic gene expression have not been determined.

Taken together, the data suggest a need for additional information on the role of propionate on expression of key genes for hepatic gluconeogenesis in dairy cattle. We hypothesized that increasing propionate supply would promote expression of key genes for gluconeogenesis to enhance gluconeogenic capacity in neonatal calves and lactating cows. The objectives of this study were to determine the effect of propionate on expression of key genes for gluconeogenesis in liver of neonatal calves that were metabolically naive with regard to postabsorptive propionate supply, and to determine the effects of augmenting the supply of propionate in mid-lactation dairy cows that were in positive energy balance and not challenged with regard to glucose needs.

\section{MATERIALS AND METHODS}

\section{Experimental Design and Animal Management}

All experimental procedures involving animals were approved by the Purdue University Animal Care and Use Committee.

Experiment 1. Six mid-lactation multiparous (4 in 2nd lactation and 2 in 3rd lactation) Holstein cows fitted with rumen cannulas were selected from the Purdue Dairy Research and Education Center dairy herd and used in a replicated $3 \times 3$ Latin square design. Cows were $81 \pm 14 \mathrm{DIM}$, weighed $555 \pm 41 \mathrm{~kg}$, had a BCS of $2.50 \pm 0.25$, with a milk production of 35 $\pm 7 \mathrm{~kg} / \mathrm{d}$ at the initiation of the experiment. All cows were pregnant at the time of experiment. Cows were housed in individual tie stalls and fed a TMR (Table 1) delivered once daily at $0600 \mathrm{~h}$ in an amount to achieve approximately $10 \%$ feed refusals over the following 24-h interval. Dietary ingredients were analyzed for DM once weekly and used to make adjustments to the ration. All corn- and soybean-based ingredients are genetically modified, and other ingredients are not genetically modified. Cows had free access to feed and water except for 20 min twice daily when they were moved to the milking parlor. Feed intake was measured daily by the difference for each cow from the quantities of feed issued and feed refused. Samples of TMR were collected once per week and analyzed for chemical composition using wet chemistry methods (Dairy One, Ithaca, NY). Dry matter intake was calculated using the DM content of the TMR offered. Cows were milked twice daily, and individual milk yields were determined electronically at each milking (Herd Master Galaxy Management, AlfaLaval Agri Inc., St. Louis, MO).

The experiment was $21 \mathrm{~d}$ in duration and consisted of three 7-d periods. Each period consisted of a $6-d$ washout phase when cows were fed a TMR for ad libitum feed intake and an 8-h infusion phase when cows received postruminal infusion of glucose, propionate, or water. On d 7 of each period, cows were fitted with indwelling jugular catheters for blood sampling; infusion lines were extended through the rumen cannula to the abomasum as previously described (Gressley et al., 2006). Baseline $(0 \mathrm{~h})$ blood samples were collected for each cow at $4 \mathrm{~h}$ after morning feeding, and postruminal infusions were initiated and administered for the subsequent 8 -h period using a peristaltic pump. Treatment solutions were prepared by dissolving $160.4 \mathrm{~g}(1.68 \mathrm{~mol})$ of sodium propionate or $150.4 \mathrm{~g}(0.84 \mathrm{~mol})$ of glucose, respectively, in $4.8 \mathrm{~L}$ of deionized water. Concentrations of propionate solution and glucose solution were 0.35 and $0.175 \mathrm{~mol} / \mathrm{L}$, respectively, and $4.8 \mathrm{~L}$ of each solution or water were delivered into the abomasum at a constant rate of $10 \mathrm{~mL} / \mathrm{min}$ over the 8 -h period. Propionate infusion was designed to augment the supply of propionate to each cow by approximately $25 \%$ using previously reported net portal vein appearance data for propionate in lactating dairy cows (Reynolds et al., 1988) assuming complete absorption of infused propionate. The quantities of propionate and glucose infused were designed to be isoenergetic. Cows were fed their daily TMR at the beginning of the infusion period, and DMI was determined over the subsequent 8-h and 24-h periods. 
Experiment 2. Twelve male Holstein calves (39 $\pm 4 \mathrm{~kg}$ initial BW) were blocked by birth date and assigned to receive, at $7 \mathrm{~d}$ of age, either propionate infusion, acetate infusion, or saline infusion. All calves received $3.8 \mathrm{~L}$ of superior colostrum for the first feeding postpartum, and $1.9 \mathrm{~L}$ of superior colostrum during the first $48 \mathrm{~h}$ of life for a total of $5.7 \mathrm{~L}$. Calves were then subsequently received milk at $10 \%$ of $\mathrm{BW}$ in 2 equal feedings per day. Calves were housed in a drying pen for the first $24 \mathrm{~h}$, and then moved to individual calf hutches. On the day of infusion, calves were fitted with indwelling catheters in the right and left jugular veins between 0600 and $0700 \mathrm{~h}$. One catheter was used for infusion and the other was maintained for blood sampling. Two hours after feeding, baseline blood samples were collected and calves were given jugular infusions of either propionate at $2 \mathrm{mmol} \cdot \mathrm{h}^{-1} \cdot\left(\mathrm{BW}^{0.75}\right)^{-1}$, acetate at $3.5 \mathrm{mmol} \cdot \mathrm{h}^{-1} \cdot\left(\mathrm{BW}^{0.75}\right)^{-1}$, or saline at $4 \mathrm{~mL} / \mathrm{min}$ over

Table 1. Ingredients and nutrient composition of diets fed to cows in the propionate infusion experiment

\begin{tabular}{|c|c|c|}
\hline Item & 1st square ${ }^{1}$ & 2nd square ${ }^{1}$ \\
\hline \multicolumn{3}{|l|}{ Ingredient, $\%$ of DM } \\
\hline Corn silage & 34.24 & 35.01 \\
\hline Alfalfa silage & 17.24 & 19.53 \\
\hline Grass hay & 3.27 & - \\
\hline Wheat straw & 0.88 & 1.77 \\
\hline High-moisture corn & 18.50 & 17.41 \\
\hline Soybean meal & 8.62 & 9.52 \\
\hline Soybean hulls pellet & 3.49 & 3.50 \\
\hline Megalac $^{2}$ & 0.93 & - \\
\hline AA blend ${ }^{3}$ & 3.62 & 2.26 \\
\hline Supplement $^{4}$ & 9.21 & 7.13 \\
\hline Double S molasses & - & 3.87 \\
\hline \multicolumn{3}{|c|}{$\begin{array}{l}\text { Chemical composition, }{ }^{5} \% \text { of DM } \\
\text { (unless otherwise noted) }\end{array}$} \\
\hline $\mathrm{CP}$ & 16.08 & 15.63 \\
\hline $\mathrm{ADF}$ & 22.15 & 21.58 \\
\hline $\mathrm{NDF}$ & 32.38 & 31.65 \\
\hline $\mathrm{NE}_{\mathrm{L}}, \mathrm{Mcal} / \mathrm{kg}$ & 1.66 & 1.67 \\
\hline $\mathrm{Ca}$ & 0.99 & 0.77 \\
\hline $\mathrm{P}$ & 0.42 & 0.38 \\
\hline $\mathrm{Mg}$ & 0.35 & 0.38 \\
\hline$K^{\circ}$ & 1.57 & 1.41 \\
\hline $\mathrm{Na}$ & 0.40 & 0.42 \\
\hline
\end{tabular}

${ }^{1}$ Rations used in the 2 squares of experiment conducted in March and July, respectively.

${ }^{2}$ Purchased from Church \& Dwight Co. Inc., Princeton, NJ.

${ }^{3}$ Purchased from Venture Milling, Salisbury, MD. Ingredients contained 60\% SoyPlus VM Nov and 40\% LysAAmet.

${ }^{4}$ Contained $55.4 \%$ ground corn grain, $3.125 \%$ urea, $10 \%$ calcium carbonate, $6.25 \%$ dicalcium phosphate, $8.125 \%$ sodium bicarbonate, $2.5 \%$ magnesium oxide, $5 \% \mathrm{NaCl}, 2.5 \%$ calcium sulfate, $3.25 \%$ yeast culture (Diamond V Mills, Cedar Rapids, IA), 0.35\% niacinamide (99\% niacin), $0.275 \%$ vitamin E $44,000 \mathrm{IU} / \mathrm{kg}, 0.075 \%$ Rumensin $90,1.65 \%$ Omnigen AF (Prince-Agri Products, Quincy, IL), and 1.5\% PU Dairy premix (containing $16.11 \% \mathrm{Ca}, 2.11 \% \mathrm{~S}, 31,505 \mathrm{mg} / \mathrm{kg} \mathrm{Zn}, 8,036 \mathrm{mg} /$ $\mathrm{kg} \mathrm{Cu}, 26,020 \mathrm{mg} / \mathrm{kg} \mathrm{Mn}, 140 \mathrm{mg} / \mathrm{kg} \mathrm{Se}, 473 \mathrm{mg} / \mathrm{kg} \mathrm{Co}, 284 \mathrm{mg} / \mathrm{kg}$ $\mathrm{I}, 1,440 \mathrm{~kg} \mathrm{IU} / \mathrm{kg}$ vitamin A, $416 \mathrm{~kg} \mathrm{IU} / \mathrm{kg}$ vitamin $\mathrm{D}, 6,647 \mathrm{IU} / \mathrm{kg}$ vitamin $\mathrm{E}$ ).

${ }^{5}$ Mean values of 4 TMR samples. an 8 -h period using a peristaltic pump. The quantities of acetate and propionate infused were designed to be isoenergetic and the volume for all infusates delivered over the 8-h period was $1.9 \mathrm{~L}$.

\section{Sample Collection and Analysis}

For experiments 1 and 2, blood samples were collected from indwelling jugular catheters and transferred to evacuated tubes (Becton Dickinson, Rutherford, NJ). Blood samples were collected just before infusion and at $2,4,6$, and $8 \mathrm{~h}$ relative to the start of infusion. Collection tubes for plasma glucose analysis contained sodium fluoride and potassium oxalate. Tubes for plasma VFA analysis contained lithium heparin. Tubes for plasma glucagon analysis contained $\mathrm{K}_{2}$-EDTA. A serum separator tube was used for serum collection. Tubes for plasma preparation were put on ice immediately after sampling, then centrifuged at $4^{\circ} \mathrm{C}$ at $3,000 \times g$ for 20 min. Tubes for serum preparation were allowed to clot for $30 \mathrm{~min}$ at room temperature before centrifugation for $15 \mathrm{~min}$ at $1,000 \times \mathrm{g}$. Plasma and serum were stored at $-20^{\circ} \mathrm{C}$ until analysis. Plasma for glucagon analysis was aliquoted into 2 borosilicate glass culture tubes containing $500 \mathrm{kIU}$ of aprotinin per $\mathrm{mL}$ of plasma and frozen at $-20^{\circ} \mathrm{C}$ pending analysis. For experiment 2, blood samples were collected from the opposite indwelling jugular catheter used for infusion. On the rare occasion that blood could not be drawn using catheters, blood samples were collected by jugular venipuncture for calves and coccygeal vein or artery for cows.

Plasma was analyzed for glucose (Wako Chemicals USA Inc., Richmond, VA). Serum insulin was quantified by a solid-phase ${ }^{125}$ I radioimmunoassay kit (CoatA-Count Insulin, Siemens Medical Solutions USA Inc., Malvern, PA). The intra- and interassay CV for insulin was 1.9 and $4.8 \%$, respectively. Glucagon was quantified by a ${ }^{125}$ I radioimmunoassay kit (Double Antibody Glucagon, Siemens Medical Solutions USA Inc.) with an intra- and interassay CV of 8.7 and $4.4 \%$, respectively.

Plasma propionate, acetate, and butyrate were quantified by using liquid chromatography-mass spectrometry (LC/MS) based on Group Specific Internal Standard Technology labeling method (Jannasch et al., 2011) at the Bindley Bioscience Center (Purdue University Discovery Park). For sample and standard derivatization, $100 \mu \mathrm{L}$ of plasma or standard mixture (containing $100 \mathrm{ng} / \mu \mathrm{L}$ of propionic acid, acetic acid, and butyric acid) was mixed with $10 \mu \mathrm{L}$ of freshly made $\mathrm{N}$-(3-dimethylaminopropyl)-N'-ethylcarbodiimide hydrochloride $(200 \mathrm{mg} / \mathrm{mL}$; Sigma-Aldrich, St. Louis, $\mathrm{MO})$ and $10 \mu \mathrm{L}$ of $6 \mathrm{M}$ aniline ( $\mathrm{pH} 4.5)$. The aniline mixed with the sample was unlabeled (light), while 
the aniline mixed with the standard solution was ${ }^{13} \mathrm{C}_{6^{-}}$ aniline (heavy). After $2 \mathrm{~h}$ of incubation, $5 \mu \mathrm{L}$ of triethylamine ( $\mathrm{pH}$ 8.0, Sigma-Aldrich) was added to stop the reactions; $20 \mu \mathrm{L}$ of the derivatized sample and $20 \mu \mathrm{L}$ of the derivatized standards mixture were mixed and quantified using LC/MS (6460 Triple Quadrupole LC/ MS/MS, Agilent Technologies Inc., Santa Clara, CA). The absolute quantity of individual short-chain FA was calculated from the measured isotope ratios (light/ heavy) as described by Jannasch et al. (2011).

Liver biopsy samples (500 to 1,000 mg) were obtained by percutaneous needle biopsy at the end of 8-h infusion of each period in experiment 1 , and at the end of the 8-h infusion in experiment 2 as previously described (Hammon et al., 2003). One aliquot of liver sample (200 to $400 \mathrm{mg}$ ) was rinsed in saline and transferred to plastic vials containing $4 \mathrm{~mL}$ of Trizol reagent (Life Technologies Corp., Carlsbad, CA), frozen in liquid nitrogen and stored in $-80^{\circ} \mathrm{C}$ pending mRNA extraction and analysis. For experiment 1, a second aliquot of liver was placed in Dulbecco's modified Eagle's medium, supplemented with $1 \%$ BSA, transported back to the laboratory within $15 \mathrm{~min}$, and used for ${ }^{13} \mathrm{C}$-metabolite flux analysis.

Total RNA was isolated using Trizol reagent and quantified by absorbance at $260 \mathrm{~nm}$ using a ND-1000 (NanoDrop Technologies Inc., Wilmington, DE). A $50 \mu \mathrm{g}$ of the resulting RNA was further purified using RNeasy Mini Kit (Qiagen Inc., Thousand Oaks, CA). A total of $2 \mu \mathrm{g}$ of purified RNA sample was reverse transcribed to cDNA using an Omniscript reverse transcriptase kit (Qiagen Inc.), random decamers (Ambion, Foster City, CA), and oligo-dT (Qiagen Inc.). The abundance of cDNA product for each RNA sample was quantified using real-time PCR, Brilliant III Ultra-Fast SYBR Green QPCR Master Mix (Agilent Technologies Inc.) with primers described below. A cDNA pool was generated from an equivalent quantity of cDNA from each sample. A 1:4 dilution series of the cDNA pool was used to generate the standard curve. No template control (using water as a template) and no reverse transcription control (using RNA pool as a template) were included in the real-time PCR analysis. The forward and reverse primers for PCK1, PCK2, $P C, G 6 P C, \mathrm{GAPDH}$, and $18 S$ were bovine PCK1 (GenBank accession: NM_174737.2), AGGGAAATAGCAGGCTCCAGGAAA, CACACGCATGTGCACACACACATA; bovine PCK2 (GenBank accession: NM_001205594.1), TGACTGGGCAAGGGGAGCCG, GGGGCCACCCCAAAGAAGCC; bovine $P C$ (GenBank accession: NM_177946.4), CCACGAGT TCTCCAACACCT, TTCTCCTCCAGCTCCTCGTA; bovine G6PC (GenBank accession: NM_001076124.2), TGATGGACCAAGAAAGATCCAGGC, TATG-
GATTGACCTCACTGGCCCTCTT; bovine GAPDH (GenBank accession: NM_001034034.2), CATGTT TGTGATGGGCGTGAACCA, TGATGGCGTGGACAGTGGTCATAA; bovine $18 S$ (GenBank accession: NR_036642.1), ACCCATTCGAACGTCTGCCCTATT, TCCTTGGATGTGGTAGCCGTTTCT. Reactions were as follows: 1 cycle at $95^{\circ} \mathrm{C}$ for $3 \mathrm{~min} ; 40$ cycles at $95^{\circ} \mathrm{C}$ for $10 \mathrm{~s}, 60^{\circ} \mathrm{C}$ for $20 \mathrm{~s}$; 1 cycle at $95^{\circ} \mathrm{C}$ for $1 \mathrm{~min}, 55^{\circ} \mathrm{C}$ for $30 \mathrm{~s}$, and $95^{\circ} \mathrm{C}$ for $30 \mathrm{~s}$. Samples were analyzed in triplicate and PCR reaction efficiencies were between 90 and $110 \%$. The $\mathrm{Ct}$ values for treatments were evaluated independently for GAPDH and $18 \mathrm{~S}$ as potential housekeeping genes. No effect of treatment on either transcript was found. The copy number for $18 \mathrm{~S}$ showed less variation among samples compared with GAPDH and mean values for transcripts evaluated were normalized to mRNA abundance of $18 S$ within each sample. Data are expressed as arbitrary units of mRNA adjusted for $18 S$ abundance.

For ${ }^{13} \mathrm{C}$-metabolite flux analysis, liver explants (3-4 $\mathrm{mm}$ thick and $9 \mathrm{~mm}$ in diameter) were prepared using a razor blade, placed in $20-\mathrm{mL}$ glass scintillation vials (Research Products International Corp., Mount Prospect, IL), gassed with $95 \% \mathrm{O}_{2}: 5 \% \mathrm{CO}_{2}$, and incubated at $37^{\circ} \mathrm{C}$ for $2 \mathrm{~h}$ in glucose-free Dulbecco's modified Eagle's medium supplemented with $1 \%$ BSA, 2.5 $\mathrm{m} M$ sodium propionate $(49.5 \%$ atom percent excess of $\left[{ }^{13} \mathrm{C}_{3}\right]$ propionate), and $1 \mathrm{~m} M$ sodium lactate. Incubations were terminated by placing on ice; the liver explant was removed, weighed, and frozen at $-80^{\circ} \mathrm{C}$, then shipped on dry ice to the University of Maryland and processed for the ${ }^{13} \mathrm{C}$-mass isotopomer distribution analysis of metabolites. Briefly, liver tissue was homogenized in $1 \mathrm{~mL}$ of sulfosalicylic acid $(50 \%$, wt/ vol) and centrifuged at $10,000 \times g$ at $4^{\circ} \mathrm{C}$ for $20 \mathrm{~min}$. The acid-supernatant was desalted by cation exchange (AG 50W-X8, $\mathrm{H}^{+}$form; BioRad, Hercules, CA). Amino acids were eluted with $2 \mathrm{M} \mathrm{NH}_{4} \mathrm{OH}$ followed by water and lyophilized to dryness. The AA were converted to their tert-butyl dimethylsilyl derivatives (Calder et al., 1999) before loaded onto GC-MS (HP 5973N Mass Selective Detector, Agilent, Palo Alto, CA). The MS was set to monitor selected ions of $m / z$ (alanine 321 to 324 , aspartate 421 to 425 , glutamate 435 to 440 , and serine 533 to 536) under methane negative chemical ionization conditions. The normalized crude ion abundances of the enriched analytes were corrected for the natural abundance of stable isotopes present in the original molecule and that contributed by the derivative using the matrix approach (Fernandez et al., 1996).

The ${ }^{13} \mathrm{C}$-isotopomer enrichments were expressed as tracer: trace ratios (TTR), which was $\mathrm{mol}^{13} \mathrm{C}$ - isotopomer $[\mathrm{M}+\mathrm{n}]$ per $100 \mathrm{~mol}{ }^{12} \mathrm{C}$-isotopomer $[\mathrm{M}+0]$, where $\mathrm{n}$ equals the number of ${ }^{13} \mathrm{C}$-labeled carbons in 
the analyte. The fractional contribution of precursor to product was calculated as the ratio of TTR product to TTR precursor (El-Kadi et al., 2009). Entry of [1, 2, $3-{ }^{13} \mathrm{C}$ ] propionate to the tricarboxylic acid cycle introduces $\left[1,2,3-{ }^{13} \mathrm{C}\right]$ oxaloacetate $(\mathbf{O A A})$ containing ${ }^{13} \mathrm{C}$ in carbons 1,2 , and 3 in the first pass. The $\left[1,2,3-{ }^{13} \mathrm{C}\right]$ OAA will subsequently randomize to $\left[2,3,4{ }^{13} \mathrm{C}\right]$ OAA due to the reversible reactions of malate dehydrogenase and fumarase. These $2[\mathrm{M}+3]$ OAA isotopomers are unique products of propionate carboxylation and will achieve a metabolic equilibrium with their transamination partner $[\mathrm{M}+3]$ aspartate isotopomers. Thus, the proportion of OAA flux derived from metabolism of propionate was calculated as the mole ratio of $[\mathrm{M}+3]$ aspartate to $[\mathrm{M}+3]$ propionate. Oxaloacetate is either metabolized as an intermediate through the TCA cycle or converted to PEP via $P C K$. For metabolism in the TCA cycle, OAA and acetyl-CoA form citrate. Citrate is decarboxylated to form ketoglutarate, which is in metabolic equilibrium with its transamination partner, glutamate. The transformation of positional isotopomers of OAA through the TCA has been extensively demonstrated by Lee (1993). Briefly, all ${ }^{13} \mathrm{C}$-isotopomer $[\mathrm{M}+\mathrm{n}]$ of glutamate is originated from $[\mathrm{M}+3]$ propionate via the TCA cycle. Therefore, the TCA cycle flux from propionate was expressed as the percentage of total ${ }^{13} \mathrm{C}$ in glutamate relative to the total ${ }^{13} \mathrm{C}$ in propionate. In addition, via $P C K,\left[1,2,3-{ }^{13} \mathrm{C}\right] \mathrm{OAA}$ is converted to $[\mathrm{M}+3] \mathrm{PEP}$, and $\left[2,3,4-{ }^{13} \mathrm{C}\right]$ OAA loses one ${ }^{13} \mathrm{C}$ and forms $[\mathrm{M}+2]$ PEP. The $[\mathrm{M}+3]$ PEP can be recycled via pyruvate kinase to $[\mathrm{M}+3]$ pyruvate, which can be quantitated as analog $[\mathrm{M}+3]$ alanine. Taken together, the flux from OAA to pyruvate via $P C K$ was determined from the ratio of $[\mathrm{M}+3]$ alanine to $1 / 2[\mathrm{M}$ $+3]$ aspartate. Otherwise, because $[\mathrm{M}+3] \mathrm{PEP}$ can be used to synthesize $[\mathrm{M}+3] 3$-phosphoglycerate, which is eventually used for gluconeogenesis and because $[\mathrm{M}+$ 3] 3-phosphoglycerate is in equilibrium with its analog $[\mathrm{M}+3]$ serine, flux from OAA to glucose via $P C K$ was estimated by the ratio of $[\mathrm{M}+3]$ serine to $1 / 2[\mathrm{M}+$ 3] aspartate.

\section{Statistical Analyses}

Data were analyzed for normality using UNIVARIATE procedure of SAS 9.2, and blood insulin data in experiment 1 were transformed to achieve normality using a natural logarithm transformation. Analyses of variance of the data were performed using the Proc Mixed procedure of SAS. Experiment 1 was analyzed as a replicated $3 \times 3$ Latin square. The basic model accounted for the fixed effects of square, period, treatment, their interactions, and random effects of cow within square. No significant effects of treatment $\times$ square or treatment $\times$ period were found, and only $P$ values for treatment, time, and treatment $\times$ time are reported. In experiment 2 , the basic model accounted for the fixed effects of treatment and random effects of calf within treatment. For blood measures in both experiments, the effect of time relative to start of infusion and the interaction of time by treatment were added to the basic models with time as repeated measures. For the repeated statement, the covariance structure autoregressive (1) yielded the lowest Akaike information criteria (AIC) and was used in the final models. In addition, preplanned comparisons of paired treatments were made using Dunnett's test. The comparisons included propionate vs. water and propionate vs. glucose in experiment 1; propionate vs. saline and propionate vs. acetate in experiment 2. Data are reported as least squares means \pm SEM. Means were considered different when $P<0.05$, and tended to differ when $0.05 \leq P \leq$ 0.10 .

\section{RESULTS}

Cows and calves used did not experience any adverse/ clinical health events during the study.

\section{Experiment 1}

DMI and Milk Production. Propionate infusion did not alter $(P>0.10)$ DMI during the 8 -h and 24 -h periods relative to the start of infusion (Table 2). Milk yield on the day of infusion was not different among treatments $(P>0.10$; Table 2$)$.

mRNA Analysis. A tendency $(P=0.10)$ was found for an overall effect of infusions on $P C K 1 \mathrm{mRNA}$ abundance, but no overall treatment effects $(P>0.10)$ for PCK2, PC, and G6PC mRNA abundance (Table 2 ). Preplanned comparisons revealed a tendency for increased $P C K 1$ mRNA $(P=0.09)$ and $G 6 P C$ mRNA $(P=0.10)$ with propionate infusion compared with glucose infusion (Table 2).

${ }^{13}$ C-Metabolite Flux Analysis. The ${ }^{13}$ C-metabolite distribution analysis was used to demonstrate the effects of infusions on intracellular metabolic flux and glucose production in liver explants. No differences were found in formation of OAA from propionate, and the contribution of TCA flux from propionate among treatments (Figure 1). However, a significant overall treatment effect $(P=0.01)$ and tendency $(P=0.10)$ were found for formation of pyruvate from OAA via $P C K$, and production of glucose from OAA via $P C K$, respectively (Figure 1). Consistent with the gene expression data, preplanned comparisons indicated that 
Table 2. Effects of postruminal propionate infusion on DMI, milk yield, blood concentrations of VFA, glucose, and hormones, and hepatic mRNA expression in mid-lactation dairy cows ${ }^{1}$

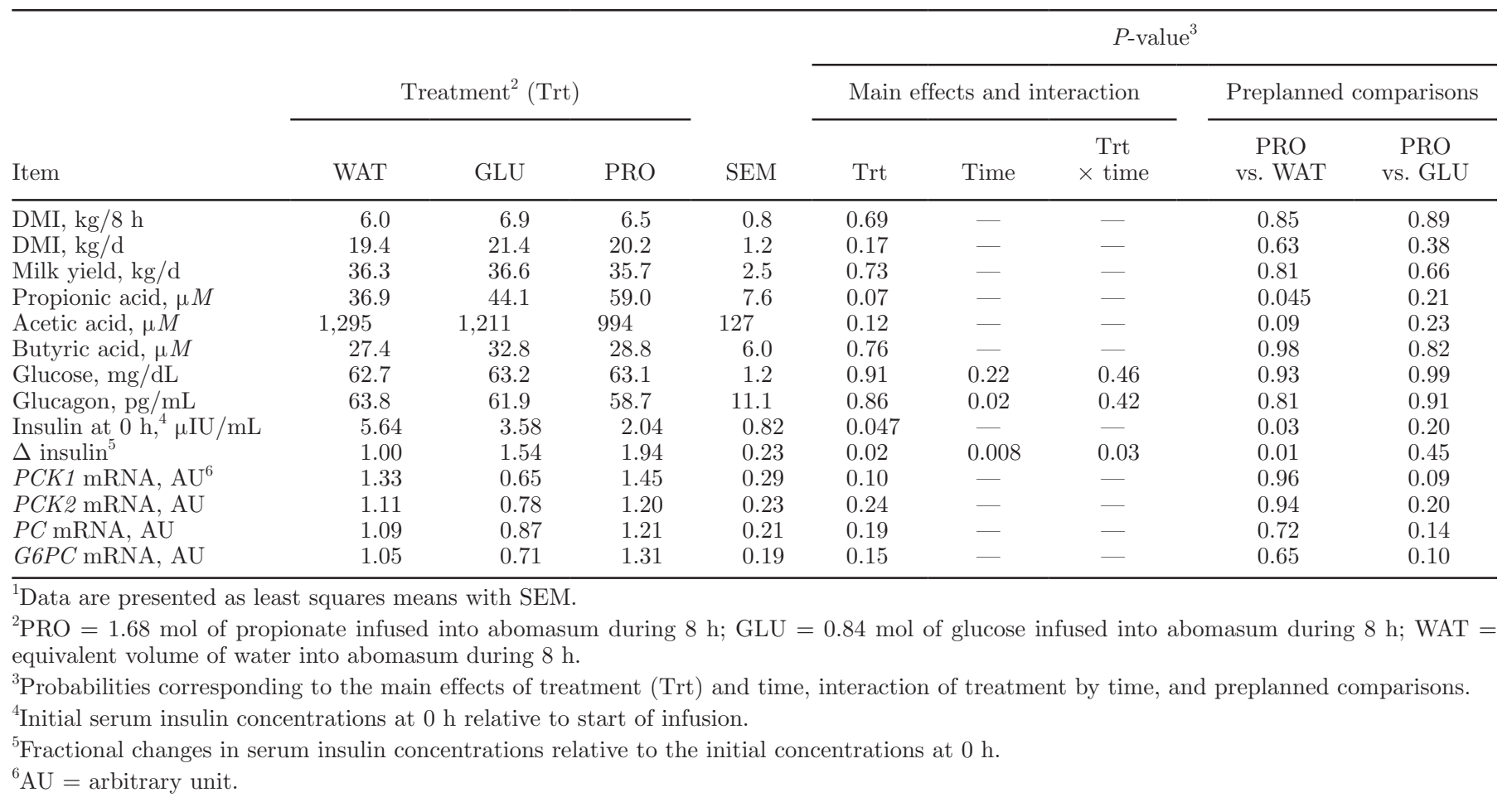

propionate infusion tended to increase $(0.05<P<$ $0.10)$ the flux from OAA to pyruvate via $P C K$ and the contribution of OAA to glucose production via $P C K$ by 30 and $60 \%$, respectively, compared with glucose infusion (Figure 1).

Plasma and Serum Metabolites and Hormones. A tendency $(P=0.07)$ was observed for an overall effect of infusions on plasma propionic acid concentrations at $8 \mathrm{~h}$ relative to start of infusion, but no differences were observed in concentrations of acetic acid and butyric acid (Table 2). Preplanned comparisons indicated elevated $(P=0.045)$ propionic acid concentration and a tendency $(P=0.09)$ for reduced acetic acid concentration at $8 \mathrm{~h}$ relative to start of infusion with propionate infusion compared with water infusion.

No square and period effects $(P>0.10)$ were found on plasma concentrations of glucose and glucagon. No period effect $(P>0.10)$ was found, and a square effect $(P=0.02)$ was observed on serum insulin concentration. No treatment effects $(P>0.10)$ were detected for concentrations of plasma glucose and glucagon (Table $2)$. A time effect $(P=0.02)$ was detected on glucagon concentrations, but no time effect $(P>0.10)$ was observed on glucose concentrations. Due to the differences $(P=0.05)$ for preinfusion $(0 \mathrm{~h})$ insulin concentration among treatment groups, fractional changes in insulin concentrations relative to the initial concentrations at
$0 \mathrm{~h}$ were used to determine the treatment effects on serum insulin concentrations (Table 2). A main effect $(P=0.02)$ of treatments on serum insulin was found, and propionate was elevated $(P=0.01)$ serum insulin concentrations compared with water infusion (Table 2; Figure 2). Time effect $(P=0.008)$ and treatment by time interaction $(P=0.03)$ on insulin concentration were also observed (Table 2; Figure 2).

\section{Experiment 2}

mRNA Analysis. An overall effect $(P=0.008)$ of infusions on PCK1 mRNA abundance (Table 3) was observed. Compared with saline infusion, propionate infusion significantly increased $(P=0.005) P C K 1 \mathrm{mRNA}$ expression (Table 3). Likewise, the abundance of $G 6 P C$ mRNA was different $(P=0.04)$ among treatments, and a tendency $(P=0.08)$ was observed for increased $G 6 P C$ mRNA in response to propionate compared with saline infusion (Table 3). The $P C$ mRNA expression was not different among treatments (Table 3 ).

Plasma and Serum Metabolites and Hormones. Blood concentrations of glucose, glucagon, and insulin were not different $(P>0.10)$ among treatments. A time effect $(P<0.01)$ was observed on blood glucagon and insulin concentrations, but no time effect $(P>$ $0.10)$ was found on glucose concentrations. A tendency 
A

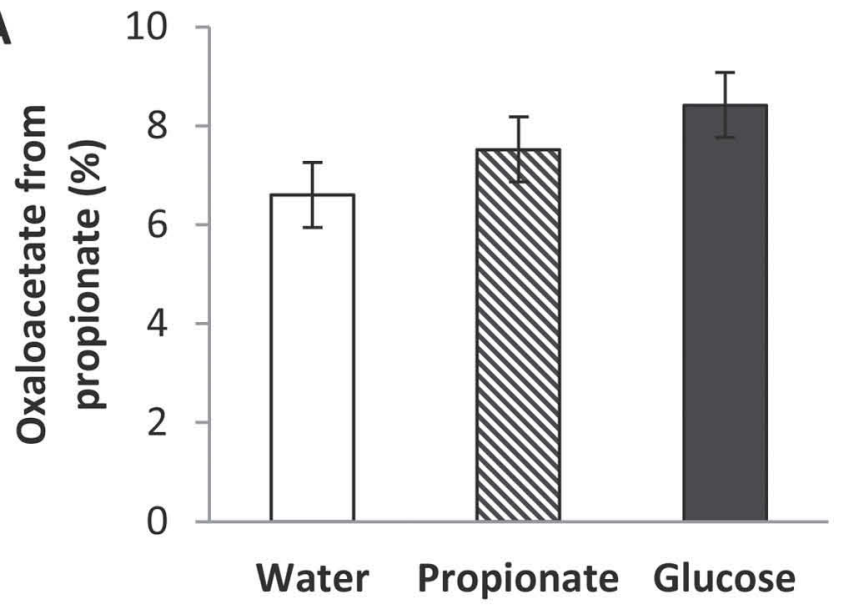

C

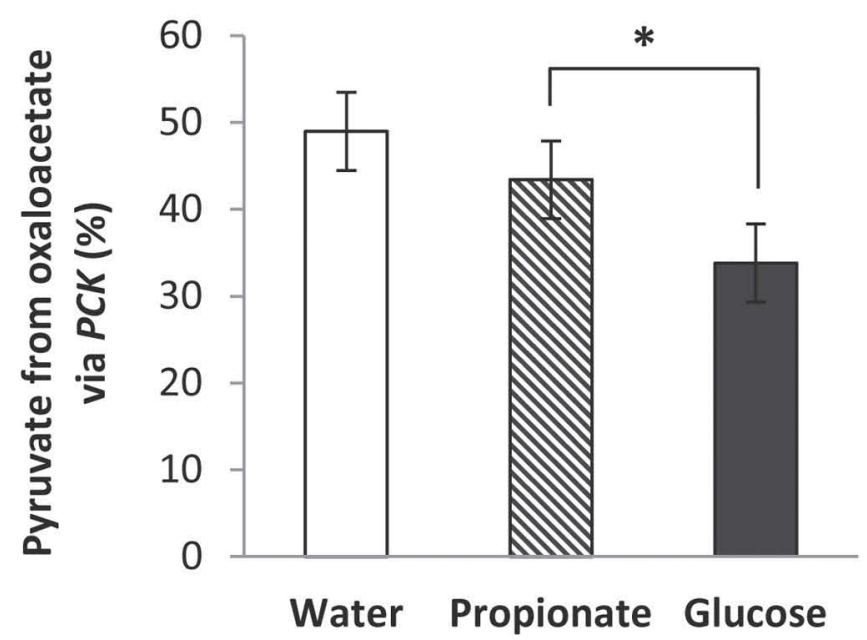

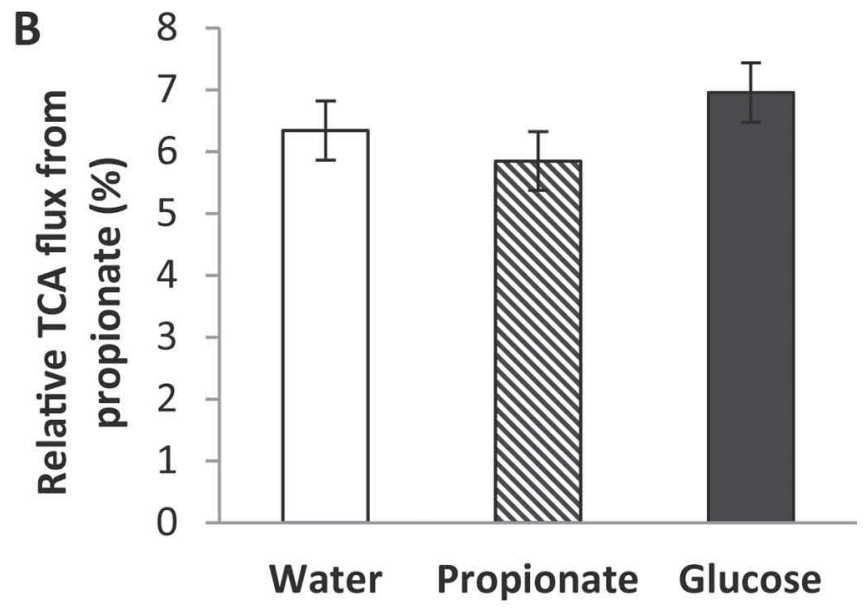

D

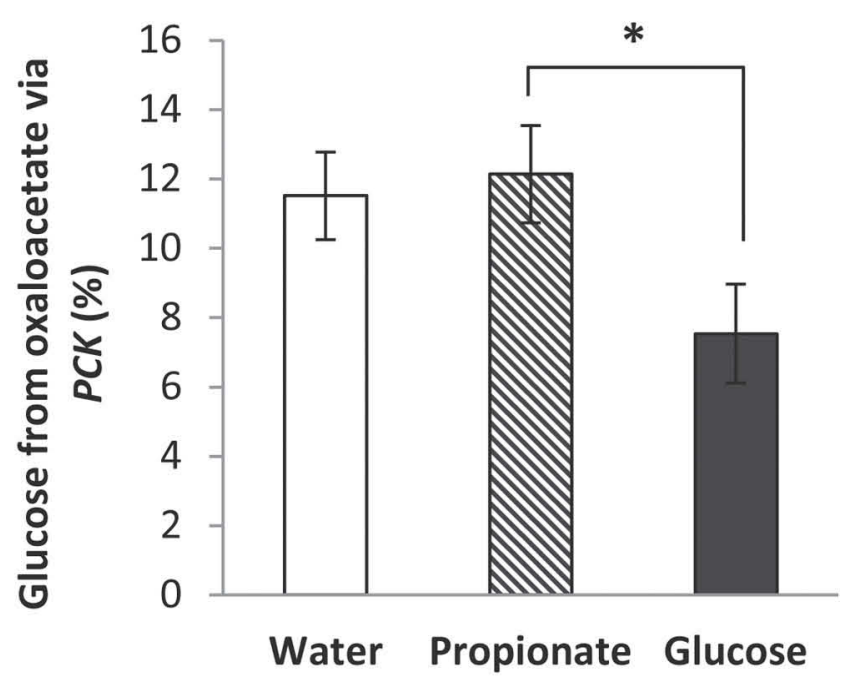

Figure 1. Effects of postruminal propionate infusion on $\left[{ }^{13} \mathrm{C}\right]$ metabolite flux in liver explants. Propionate (1.68 mol), glucose $(0.84 \mathrm{~mol})$, or an equivalent volume of water was infused into the abomasum of mid-lactation dairy cows over $8 \mathrm{~h}$ during each period of a replicated $3 \times 3 \mathrm{Latin}$ square design. Liver explants cultures were used to measure (A) oxaloacetate formation from propionate, (B) tricarboxylic acid (TCA) cycle flux from propionate, $(\mathrm{C})$ pyruvate formation from oxaloacetate via $P C K$, and $(\mathrm{D})$ glucose production from oxaloacetate via $P C K$. An asterisk $(*)$ indicates a tendency for difference $(0.05<P<0.10)$. Error bars are standard error of the least squares means.

$(0.05 \leq P \leq 0.10)$ for time by treatment interaction on blood glucagon and insulin concentrations was detected (Table 3).

\section{DISCUSSION}

Previous studies indicated that hepatic PCK1 mRNA expression in dairy cows was increased when DMI was increased during early lactation (Greenfield et al., 2000; Agca et al., 2002) and with monensin feeding in transition cows (Karcher et al., 2007). The fact that both of these conditions likely increase ruminal propionate supply suggests a possible role of propionate in regulating the expression of $P C K 1 \mathrm{mRNA}$ in liver. In this study, we demonstrate that hepatic PCK1 mRNA expression is positively regulated in response to increased supply of propionate in mid-lactation cows and neonatal calves. The increased PCK1 mRNA expression was accompanied with higher glucose production in liver of mid-lactation cows. We used mid-lactation cows to determine the effect of propionate supply on hepatic gene expression in animals that were in positive energy balance and not challenged with regard to glucose needs. In neonatal calves, hepatic gluconeogenesis is established in early life to prevent hypoglycemia because lactose intake from milk cannot meet glucose requirements (Hammon et al., 2013). 


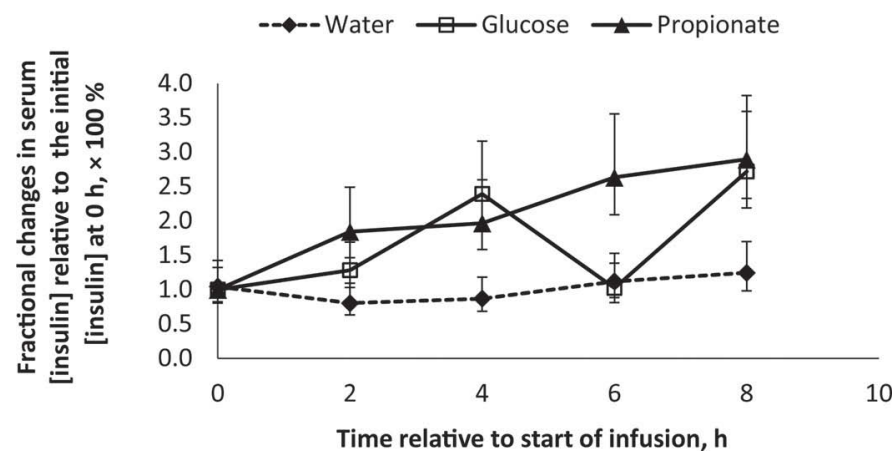

Figure 2. Effect of postruminal propionate infusion on fractional changes in serum insulin concentrations in mid-lactation dairy cows. Propionate $(1.68 \mathrm{~mol})$, glucose $(0.84 \mathrm{~mol})$, or an equivalent volume of water was infused into the abomasum over an 8-h interval in a replicated $3 \times 3$ Latin square design. Blood samples were collected every $2 \mathrm{~h}$, and fractional changes in serum insulin concentrations were calculated relative to the initial concentrations at $0 \mathrm{~h}$. Data are least squares means \pm SEM for each treatment at each time point. Effects of treatment, time, and treatment by time interaction $(P<0.05)$ were found. Propionate infusion increased serum insulin concentrations compared with water infusion $(P=0.01)$.

Neonatal calves were used to assess the effect of shortterm changes in propionate supply in animals that were naive with regard to the supply for propionate to liver from rumen fermentation.

The experiments reported here used an isoenergetic infusion of acetate or propionate for calves. Infusion of acetate for calves matched the energy supply using an alternative VFA source. Glucose and propionate were used for lactating cows to provide equal quantities of glucose carbon load as either preformed glucose or precursor (propionate) form. An equal volume of saline or water was used for calves and cows, respectively, to control for the effects of the infusion protocol. The postruminal infusion technique used for experiment 1 supplied propionate or glucose directly to the abomasum to avoid disrupting rumen fermentation. For the lactating cows, the level of propionate infused was determined form the quantity needed to augment the supply of propionate across portal-drained visceral in lactating dairy cows by approximately $25 \%$ based on net flux measurements (Reynolds et al., 1988), assuming a $100 \%$ net portal vein appearance for infused propionate. The propionate infusion rate for calves, 2 $\mathrm{mmol} \cdot \mathrm{h}^{-1} \cdot\left(\mathrm{BW}^{0.75}\right)^{-1}$, provided the same level of propionate per unit of metabolic BW.

The increase in propionate supply for the cows also matches the proportional increase in ruminal propionate production when monensin is fed given that the addition of $420 \mathrm{mg} / \mathrm{d}$ monensin increased the molar percentage of propionate produced in the rumen from 25 to $30 \%$ without altering feed intake (Sauer et al., 1989). Assuming a net portal appearance of propionate of $0.79 \mathrm{~mol} / \mathrm{h}$ without monensin (Reynolds et al., 1988), this value is estimated at $0.95 \mathrm{~mol} / \mathrm{h}$ with addition of monensin in the diet of early lactation dairy cows, resulting in approximately $20 \%$ increase in net flux of propionate across portal-drained visceral, and similar to the level of propionate supplied in our study. The lack of difference in DMI in the present study supports a similar supply of propionate from the rumen for all treatment groups and eliminates any possible confounding effects of feed intake on hepatic gene expression.

In ruminants, approximate 91 to $95 \%$ of propionate produced in the rumen is recovered in the portal vein, of which over $90 \%$ is efficiently taken up by the liver (Kristensen, 2005; Nozière et al., 2010), and approximately $90 \%$ of propionate taken up by the liver is used for glucose production (Lomax and Baird, 1983;

Table 3. Effects of intravenous propionate infusion on blood concentrations of glucose and hormones and hepatic mRNA expression in neonatal calves $^{1}$

\section{$P$-value ${ }^{3}$}

\begin{tabular}{|c|c|c|c|c|c|c|c|c|c|}
\hline \multirow[b]{3}{*}{ Item } & \multirow{2}{*}{\multicolumn{3}{|c|}{ Treatment $^{2}(\mathrm{Trt})$}} & & \multirow{2}{*}{\multicolumn{3}{|c|}{ Main effects and interaction }} & & \\
\hline & & & & & & & & \multicolumn{2}{|c|}{ Preplanned comparison } \\
\hline & SAL & $\mathrm{ACE}$ & $\mathrm{PRO}$ & SEM & Trt & Time & Trt $\times$ Time & $\begin{array}{c}\text { PRO } \\
\text { vs. SAL }\end{array}$ & $\begin{array}{c}\text { PRO } \\
\text { vs. ACE }\end{array}$ \\
\hline Glucagon, pg/mL & 52.2 & 52.1 & 51.6 & 10.9 & 1.00 & 0.004 & 0.07 & 1.00 & 1.00 \\
\hline Insulin, $\mu \mathrm{IU} / \mathrm{mL}$ & 11.1 & 10.2 & 9.7 & 1.5 & 0.81 & $<0.001$ & 0.08 & 0.75 & 0.96 \\
\hline$P C K 1, \mathrm{mRNA} \mathrm{AU}^{4}$ & 0.34 & 1.41 & 1.89 & 0.27 & 0.008 & - & - & 0.005 & 0.37 \\
\hline
\end{tabular}

${ }^{1}$ Data are presented as least squares means with SEM.

${ }^{2} \mathrm{PRO}=$ intravenous infusion of propionate at $2 \mathrm{mmol} / \mathrm{h}$ per $\mathrm{kg}$ of $\mathrm{BW}^{0.75}$ during $8 \mathrm{~h}$; ACE = intravenous infusion of acetate at $3.5 \mathrm{mmol} / \mathrm{h}$ per $\mathrm{kg}$ of $\mathrm{BW}^{0.75}$ during $8 \mathrm{~h}$; SAL = intravenous infusion of saline at $4 \mathrm{~mL} / \mathrm{min}$ during $8 \mathrm{~h}$.

${ }^{3}$ Probabilities corresponding to the main effects of treatment and time, interaction of treatment by time, and preplanned comparisons.

${ }^{4} \mathrm{AU}=$ arbitrary unit. 
Reynolds et al., 1988; Armentano, 1992). It has been proposed that entry of propionate into gluconeogenesis is mainly regulated via the enzyme activity of PCK1 (Aschenbach et al., 2010). Studies from nonruminant animals indicate that the abundance of $P C K 1 \mathrm{mRNA}$ and the activity of its enzyme product are directly proportional and are regulated at the transcriptional level of the PCK1 gene (Forest et al., 1997; Hanson and Reshef, 1997). The responses of PCK1 transcription to hormones is rapid; a 10-fold induction by cyclic AMP in rat liver is observed within 20 min (Lamers et al., 1982), and addition of insulin results in a $50 \%$ decrease in PCK1 mRNA abundance within $30 \mathrm{~min}$ (Granner et al., 1983). The degradation of $P C K 1 \mathrm{mRNA}$ is also rapid, with a 30-min half-life when the gene is not transcribed (Nelson et al., 1980). Therefore, the effects observed here are likely due to changes in the rate of transcription of bovine $P C K 1$, but direct measures of promoter activity are necessary to confirm the nature of this response.

In contrast to our original hypothesis, postruminal infusion of propionate to mid-lactation cows did not increase PCK1 mRNA expression compared with water control. An underlying explanation may be the elevated blood insulin concentration observed in response to propionate infusion in the current experiments. These data are consistent with previous studies that also observed an increase in circulating insulin with propionate infusion to cattle (Baird et al., 1980; Bines and Hart, 1984; Oba and Allen, 2003) and sheep (Brockman, 1990). Insulin is known to potently and rapidly repress $P C K 1$ transcription and hepatic PCK1 mRNA expression (Granner et al., 1983; Sasaki et al., 1984; Chakravarty and Hanson, 2007). Consequently, repression of PCK1 mRNA and reduced gluconeogenic capacity would be an anticipated outcome of increased propionate supply, but clearly this is not the case in vivo as the increased propionate supply is linked to increased hepatic glucose output both in the present study and a previous study (Lozano et al., 2000).

We demonstrate that the expression of PCK1 is maintained in bovine liver by the action of propionate despite almost 2 times greater serum insulin concentrations. This novel finding is consistent with generalized observations that hepatic capacity for gluconeogenesis from propionate in cattle is resistant to changes in blood insulin concentrations (Huntington et al., 2006), and a lack of specific change in rate of utilization of propionate for glucose production despite increased blood insulin in sheep (Brockman, 1990). Although the data support a generalized effect of propionate to maintain PCK1 expression and promote gluconeogenesis, additional effort is needed to better characterize the relative sensitivity of the bovine $P C K 1$ gene to changes in insulin concentration and propionate supply.

The fact that propionate maintained PCK1 mRNA expression and hepatic gluconeogenesis from propionate in the face of elevated insulin is also supported by the observation that cows given postruminal infusion of glucose had similar blood insulin concentration to cows given propionate infusion, but displayed a $50 \%$ lower expression of $P C K 1 \mathrm{mRNA}$ and similar reduction in glucose flux from OAA in liver explants cultures (Figure 3). In addition, a similar flux coefficient for OAA formation from propionate and lack of difference for TCA cycle flux between cows given glucose or propionate suggests a lack of regulation of metabolism before the OAA pool for these groups of cows (Figure 3 ). Interestingly, greater amount of OAA is converted to PEP in cows receiving propionate infusion, leading to greater flux of pyruvate from OAA and, most importantly, greater flux of OAA to glucose in cows receiving propionate infusion (Figure 3). Although our experiments do not distinguish between flux of OAA to PEP through cytosolic or mitochondrial pathways, the lack of change in PCK2 mRNA and greater abundance of PCK1 mRNA suggest increased flux from OAA to PEP in the cytosol.

Synthesis of phosphoenolpyruvate from OAA directly in the mitochondrion via $P C K 2$ balances the NADH produced during the oxidation of lactate to pyruvate in the cytosol (Croniger et al., 2002; Yang et al., 2009). In ruminants, however, gluconeogenesis from propionate is not likely to be limited by cytosolic NADH (Aiello and Armentano, 1987). Approximately $60 \%$ of propionate flux to glucose depends on the enzyme $P C K 2$ in goat hepatocytes (Aiello and Armentano, 1987). The lack of change in PCK2 mRNA with propionate infusion in mid-lactation cows is consistent with previous reports that the expression of $P C K 2$ is not acutely controlled by hormones or metabolic changes in mammals (Girard et al., 1992; Hanson and Reshef, 1997; Croniger et al., 2002). In fact, unlike PCK1, the activity and turnover rate of $P C K 2$ mRNA appear to be constitutive (Hanson and Reshef, 1997). In ruminants, the activity and mRNA expression of PCK2 lack responsiveness to development, different hormonal status (Narkewicz et al., 1993), feed restriction (Velez and Donkin, 2005), and transition to lactation (Agca et al., 2002). However, the present data indicate specific responsiveness of PCK1 to increased propionate supply.

Effects of propionate infusion in neonatal calves indicate expression of $P C K 1$ and $G 6 P C$ were increased in the absence of changes in blood insulin concentration. Glucose-6-phosphatase is the key enzyme that catalyzed the last step of gluconeogenesis and glycogenolysis to 


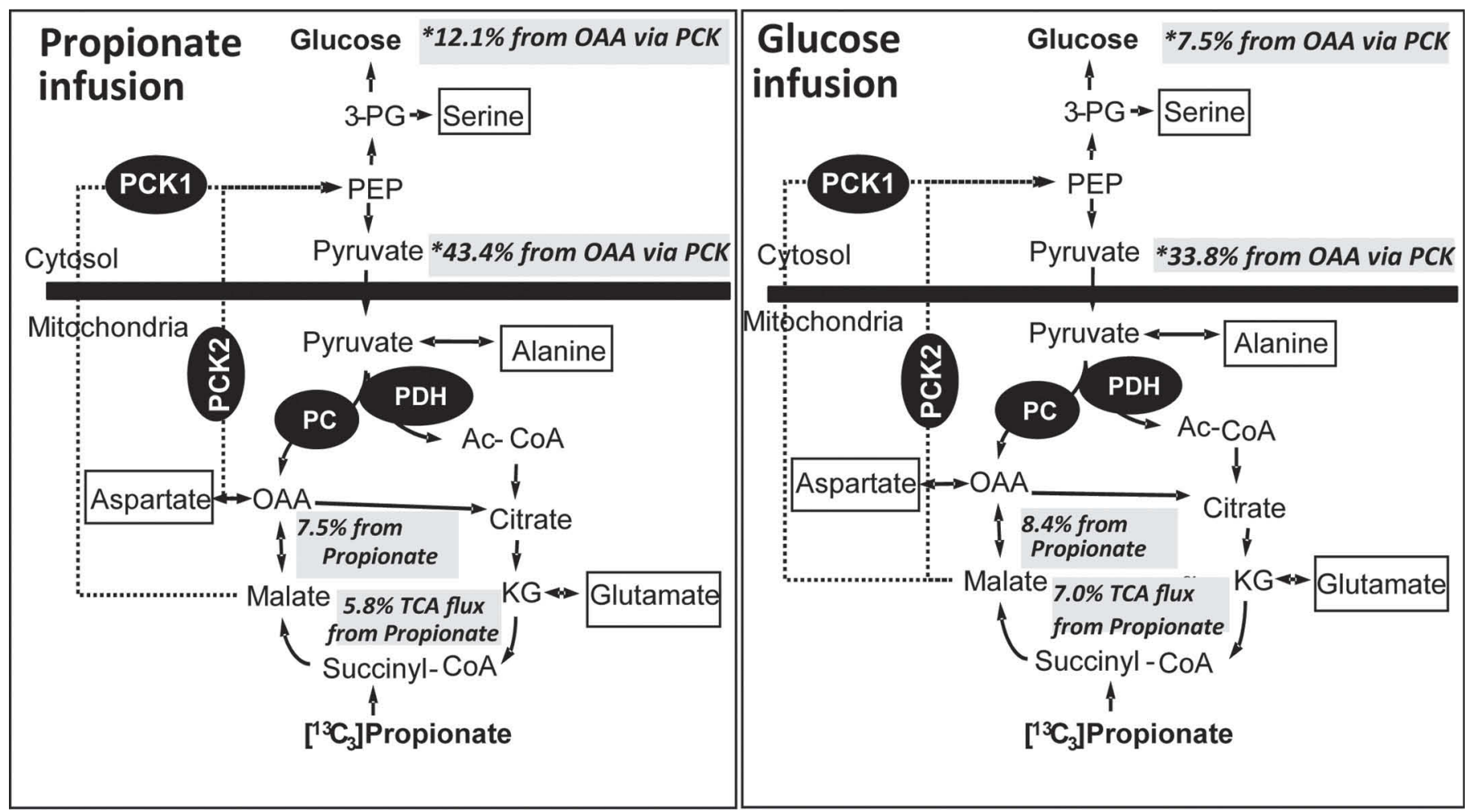

Figure 3. Overview of propionate metabolism to glucose and flux relationships among key intermediate pools for postruminal propionate (left panel) and glucose (right panel) infusions. The intermediates used for estimate the relative metabolic fluxes are marked with boxes. The relative flux from propionate to oxaloacetate (OAA) and the tricarboxylic acid (TCA) cycle flux from propionate were not different for the 2 infusion groups. The metabolic flux from OAA to phosphoenolpyruvate (PEP) via phosphoenolpyruvate carboxykinase $(P C K)$ is increased as indicated by the increased pyruvate formation from OAA via $P C K$ and gluconeogenic flux from $\mathrm{OAA}$ via $P C K$. Ac-CoA $=$ acetyl CoA; KG $=$ ketoglutarate; $3-\mathrm{PG}=3$-phosphoglycerate; $P C K 2=$ mitochondrial phosphoenolpyruvate carboxykinase $P C=$ pyruvate carboxylase; $P D H=$ pyruvate dehydrogenase.

release glucose (Nordlie and Foster, 2010). It is noteworthy that cattle liver lacks glucokinase, the enzyme that opposes $G 6 P C$ in determining the abundance of glucose-6-phosphatate in liver cells (Raggi et al., 1963). Taken together, elevated mRNA expression of PCK1 and $G 6 P C$ in calves with propionate infusion and sustained levels of PCK1 and G6PC mRNA in lactating cows despite of elevated blood insulin concentration support a role for propionate acting through regulation of gene expression to control hepatic glucose metabolism. Similar effects of propionate to induce PCK1 and G6PC mRNA expression were observed in primary cultures of rat hepatocytes where the principal response to propionate for $G 6 P C$ mRNA is linked to activity of hepatic nuclear factor $4 \alpha(\mathrm{HNF}-4 \alpha)$ on the $G 6 P C$ gene promoter (Massillon et al., 2003). In contrast to PCK1, the expression of $P C$ mRNA, which encodes a critical enzyme for gluconeogenesis from lactate, was neither changed by propionate infusion in neonatal calves nor altered by infusions in mid-lactation cows. This observation is consistent with previous studies where mRNA expression for $P C K 1$, but not $P C$, is altered in response to conditions that accompany increased ruminal propionate supply (Greenfield et al., 2000; Agca et al., 2002; Karcher et al., 2007). The current data indicate regulation of bovine $P C K 1 \mathrm{mRNA}$ by propionate in vivo. Detailed analysis of the bovine $P C K 1$ promoter and the relationship with signaling molecules including $\mathrm{HNF}-4 \alpha$ is necessary to more fully describe the direct action of propionate to control bovine PCK1 expression.

\section{CONCLUSIONS}

Our data demonstrate that mRNA for $P C K 1$ and $G 6 P C$, key gluconeogenic enzymes, are induced in response to increased propionate supply in dairy cattle. This creates a "propionate paradox" in dairy cattle where the capacity for gluconeogenesis is maintained despite elevated insulin levels due to the overriding action of propionate on the PCK1 gene. When insulin is not elevated, as observed in neonatal calves, the capacity for gluconeogenesis is likely enhanced. Overall, the data suggest propionate control of gluconeogenesis 
that is mediated at the molecular level through hepatic expression of $P C K 1$, a key flux-regulating enzyme for gluconeogenesis. Furthermore, the data indicate a feedforward mechanism that links a primary VFA produced in the rumen with its own metabolic fate, and implies an integration of hepatic metabolism in dairy cattle, at least in part, from the profile of nutrients absorbed from the rumen.

\section{ACKNOWLEDGMENTS}

This project was supported in part by National Research Initiative Competitive Grant no. 2001-3520611265 from the USDA National Institute of Food and Agriculture (Washington, DC).

\section{REFERENCES}

Agca, C., R. B. Greenfield, J. R. Hartwell, and S. S. Donkin. 2002. Cloning and characterization of bovine cytosolic and mitochondrial PEPCK during transition to lactation. Physiol. Genomics 11:53-63.

Aiello, R. J., and L. E. Armentano. 1987. Gluconeogenesis in goat hepatocytes is affected by calcium, ammonia and other key metabolites but not primarily through cytosolic redox state. Comp. Biochem. Physiol. B 88:193-201.

Armentano, L. E. 1992. Ruminant hepatic metabolism of volatile fatty acids, lactate and pyruvate. J. Nutr. 122(Suppl.):838-842.

Aschenbach, J. R., N. B. Kristensen, S. S. Donkin, H. M. Hammon, and G. B. Penner. 2010. Gluconeogenesis in dairy cows: The secret of making sweet milk from sour dough. IUBMB Life 62:869-877.

Baird, G. D., M. A. Lomax, H. W. Symonds, and S. R. Shaw. 1980 Net hepatic and splanchnic metabolism of lactate, pyruvate and propionate in dairy cows in vivo in relation to lactation and nutrient supply. Biochem. J. 186:47-57.

Bell, A. W. 1995. Regulation of organic nutrient metabolism during transition from late pregnancy to early lactation. J. Anim. Sci. $73: 2804-2819$

Bines, J. A., and I. C. Hart. 1984. The response of plasma insulin and other hormones to intraruminal infusion of VFA mixtures in cattle. Can. J. Anim. Sci. 64:304-305.

Brockman, R. P. 1990. Effect of insulin on the utilization of propionate in gluconeogenesis in sheep. Br. J. Nutr. 64:95-101.

Calder, A. G., K. E. Garden, S. E. Anderson, and G. E. Lobley. 1999. Quantitation of blood and plasma amino acids using isotope dilution electron impact gas chromatography/mass spectrometry with U-13C amino acids as internal standards. Rapid Commun. Mass Spectrom. 13:2080-2083.

Chakravarty, K., and R. W. Hanson. 2007. Insulin regulation of phosphoenolpyruvate carboxykinase-C gene transcription: The role of sterol regulatory element-binding protein 1c. Nutr. Rev. 65(s1):S47-S56.

Croniger, C. M., Y. Olswang, L. Reshef, S. C. Kalhan, S. M. Tilghman, and R. W. Hanson. 2002. Phosphoenolpyruvate carboxykinase revisited: Insights into its metabolic role. Biochem. Mol. Biol. Educ. 30:14-20.

Donkin, S. S., and L. E. Armentano. 1994. Regulation of gluconeogenesis by insulin and glucagon in the neonatal bovine. Am. J. Physiol. 266:R1229-R1237.

Donkin, S. S., and L. E. Armentano. 1995. Insulin and glucagon regulation of gluconeogenesis in preruminating and ruminating bovine. J. Anim. Sci. 73:546-551.

Duffield, T., R. Bagg, L. DesCoteaux, E. Bouchard, M. Brodeur, D. DuTremblay, G. Keefe, S. LeBlanc, and P. Dick. 2002. Prepartum monensin for the reduction of energy associated disease in postpartum dairy cows. J. Dairy Sci. 85:397-405.

Duffield, T. F., S. LeBlanc, R. Bagg, K. Leslie, J. Ten Hag, and P. Dick. 2003. Effect of a monensin controlled release capsule on metabolic parameters in transition dairy cows. J. Dairy Sci. 86:1171-1176.

El-Kadi, S. W., R. L. Baldwin, K. R. McLeod, N. E. Sunny, and B. J Bequette. 2009. Glutamate is the major anaplerotic substrate in the tricarboxylic acid cycle of isolated rumen epithelial and duodenal mucosal cells from beef cattle. J. Nutr. 139:869-875.

Fernandez, C. A., C. Des Rosiers, S. F. Previs, F. David, and H. Brunengraber. 1996. Correction of 13C mass isotopomer distributions for natural stable isotope abundance. J. Mass Spectrom. $31: 255-262$.

Forest, C., S. Franckhauser, M. Glorian, J. Antras-Ferry, D. Robin, and P. Robin. 1997. Regulation of gene transcription by fatty acids, fibrates and prostaglandins: The phosphoenolpyruvate carboxykinase gene as a model. Prostaglandins Leukot. Essent. Fatty Acids 57:47-56.

Girard, J., P. Ferré, J. P. Pégorier, and P. H. Duée. 1992. Adaptations of glucose and fatty acid metabolism during perinatal period and suckling-weaning transition. Physiol. Rev. 72:507-562.

Granner, D., T. Andreone, K. Sasaki, and E. Beale. 1983. Inhibition of transcription of the phosphoenolpyruvate carboxykinase gene by insulin. Nature 305:549-551.

Greenfield, R. B., M. J. Cecava, and S. S. Donkin. 2000. Changes in mRNA expression for gluconeogenic enzymes in liver of dairy cattle during the transition to lactation. J. Dairy Sci. 83:1228-1236.

Gressley, T. F., S. M. Reynal, J. J. Colmenero, G. A. Broderick, and L. E. Armentano. 2006. Technical note: Development of a tool to insert abomasal infusion lines into dairy cows. J. Dairy Sci. 89:3965-3967

Hammon, H. M., J. Steinhoff-Wagner, J. Flor, U. Schönhusen, and C. C. Metges. 2013. Lactation Biology Symposium: Role of colostrum and colostrum components on glucose metabolism in neonatal calves. J. Anim. Sci. 91:685-695.

Hammon, H. M., Y. Zbinden, H. Sauerwein, B. H. Breier, J. W. Blum, and S. S. Donkin. 2003. The response of the hepatic insulin-like growth factor system to growth hormone and dexamethasone in calves. J. Endocrinol. 179:427-435.

Hanson, R. W., and L. Reshef. 1997. Regulation of phosphoenolpyruvate carboxykinase (GTP) gene expression. Annu. Rev. Biochem. 66:581-611.

Huntington, G. B., D. L. Harmon, and C. J. Richards. 2006. Sites, rates, and limits of starch digestion and glucose metabolism in growing cattle. J. Anim. Sci. 84(Suppl.):E14-E24.

Jannasch, A., M. Sedlak, and J. Adamec. 2011. Quantification of pentose phosphate pathway (PPP) metabolites by liquid chromatography-mass spectrometry (LC-MS). Pages 159-171 in Metabolic Profiling. Springer, New York, NY.

Karcher, E. L., M. M. Pickett, G. A. Varga, and S. S. Donkin. 2007. Effect of dietary carbohydrate and monensin on expression of gluconeogenic enzymes in liver of transition dairy cows. J. Anim. Sci 85:690-699.

Kristensen, N. B. 2005. Splanchnic metabolism of volatile fatty acids in the dairy cow. Anim. Sci. 80:3-10.

Lamers, W. H., R. W. Hanson, and H. M. Meisner. 1982. cAMP stimulates transcription of the gene for cytosolic phosphoenolpyruvate carboxykinase in rat liver nuclei. Proc. Natl. Acad. Sci. USA 79:5137-5141.

Lee, W. N. 1993. Appendix. Analysis of tricarboxylic acid cycle using mass isotopomer ratios. J. Biol. Chem. 268:25522-25526.

Lomax, M. A., and G. D. Baird. 1983. Blood flow and nutrient exchange across the liver and gut of the dairy cow. Br. J. Nutr. 49:481-496.

Lozano, O., C. B. Theurer, A. Alio, J. T. Huber, A. Delgado-Elorduy, P. Cuneo, D. DeYoung, M. Sadik, and R. S. Swingle. 2000. Net absorption and hepatic metabolism of glucose, L-lactate, and volatile fatty acids by steers fed diets containing sorghum grain processed as dry-rolled or steam-flaked at different densities. J. Anim. Sci. 78:1364-1371. 
Massillon, D., I. J. Arinze, C. Xu, and F. Bone. 2003. Regulation of glucose-6-phosphatase gene expression in cultured hepatocytes and H4IIE cells by short-chain fatty acids: Role of hepatic nuclear

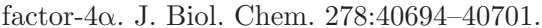

Narkewicz, M. R., T. D. Carver, and W. W. Hay. 1993. Induction of cytosolic phosphoenolpyruvate carboxykinase in the ovine fetal liver by chronic fetal hypoglycemia and hypoinsulinemia. Pediatr. Res. 33:493-496.

Nelson, K., M. A. Cimbala, and R. W. Hanson. 1980. Regulation of phosphoenolpyruvate carboxykinase (GTP) mRNA turnover in rat liver. J. Biol. Chem. 255:8509-8515.

Nordlie, R. C., and J. D. Foster. 2010. A retrospective review of the roles of multifunctional glucose-6-phosphatase in blood glucose homeostasis: Genesis of the tuning/retuning hypothesis. Life Sci. 87:339-349.

Nozière, P., I. Ortigues-Marty, C. Loncke, and D. Sauvant. 2010. Carbohydrate quantitative digestion and absorption in ruminants: From feed starch and fibre to nutrients available for tissues. Animal 4:1057-1074.

Oba, M., and M. S. Allen. 2003. Dose-response effects of intrauminal infusion of propionate on feeding behavior of lactating cows in early or midlactation. J. Dairy Sci. 86:2922-2931.

Overton, T. R., and M. R. Waldron. 2004. Nutritional management of transition dairy cows: Strategies to optimize metabolic health. J. Dairy Sci. 87:E105-E119.
Pilkis, S. J., M. R. El-Maghrabi, and T. H. Claus. 1988. Hormonal regulation of hepatic gluconeogenesis and glycolysis. Annu. Rev. Biochem. 57:755-783.

Pilkis, S. J., and D. K. Granner. 1992. Molecular physiology of the regulation of hepatic gluconeogenesis and glycolysis. Annu. Rev. Physiol. 54:885-909.

Raggi, F., D. Kronfeld, J. Bartley, and J. Luick. 1963. Soluble glucokinase activity in bovine tissues. Nature 197:190-191.

Reynolds, C. K., G. B. Huntington, H. F. Tyrrell, and P. J. Reynolds. 1988. Net metabolism of volatile fatty acids, D- $\beta$-hydroxybutyrate, nonesterified fatty acids, and blood gasses by portal-drained viscera and liver of lactating Holstein cows. J. Dairy Sci. 71:23952405.

Sasaki, K., T. P. Cripe, S. R. Koch, T. L. Andreone, D. D. Petersen, E. G. Beale, and D. K. Granner. 1984. Multihormonal regulation of phosphoenolpyruvate carboxykinase gene transcription. The dominant role of insulin. J. Biol. Chem. 259:15242-15251.

Sauer, F. D., J. K. G. Kramer, and W. J. Cantwell. 1989. Antiketogenic effects of monensin in early lactation. J. Dairy Sci. 72:436-442.

Velez, J. C., and S. S. Donkin. 2005. Feed restriction induces pyruvate carboxylase but not phosphoenolpyruvate carboxykinase in dairy cows. J. Dairy Sci. 88:2938-2948.

Yang, J., S. C. Kalhan, and R. W. Hanson. 2009. What is the metabolic role of phosphoenolpyruvate carboxykinase? J. Biol. Chem. 284:27025-27029. 